\title{
Effects of Lack of Field Trips on Leaner's Performance in Social Studies at Primary School
}

\author{
Georgina N. Sitali-Mubanga ${ }^{1, *}$, Like Raphael Lukonga ${ }^{1} \&$ Desalu D Denuga ${ }^{2}$ \\ ${ }^{1}$ Department of Education in Languages, Humanities and Commerce, Faculty of Education, \\ University of Namibia, Katima Mulilo Campus, Private Bag, 1096, Katima Mulilo, Namibia \\ ${ }^{2}$ Department of Mathematics, Science and Sport Education, Faculty of Education, University \\ of Namibia, Katima Mulilo Campus, Private Bag, 1096, Katima Mulilo, Namibia \\ *Corresponding author: Department of Education in Languages, Humanities and Commerce, \\ Faculty of Education, University of Namibia, Katima Mulilo Campus, Private Bag, 1096, \\ Katima Mulilo, Namibia.E-mail: gsitali@unam.na
}

Received: April 29, 2018

doi:10.5296/ije.v10i2.13325
Accepted: May 28, 2018 Published: June 17, 2018

URL: https://doi.org/10.5296/ije.v10i2.13325

\begin{abstract}
The utilization of field trips in teaching and learning realizes successful and proficient learning in Social Studies. A field trip is a group excursion far from the typical teaching environment for direct understanding of a noteworthy site or place of special intrigue. This investigation in this manner was outfitted towards discovering the impacts of lack of field trips towards students' scholastic execution in Social Studies at a selected school. A Qualitative research configuration was used for this examination. A specific school was chosen in the Zambezi Region of Namibia. The testing procedure utilized was random selection. The normal number of students chosen was 16, however just 14 students and 4 teachers partook. In light of the discoveries it was suggested among others that; teachers should take learners on field trips in order to advance and energize dynamic engagement in learning, self-inspiration, disclosure learning and learning by understanding.
\end{abstract}

Keywords: field trips, self-inspiration, disclosure learning, scholastic execution, dynamic engagement 


\section{Introduction}

Field trips in the Social Studies context, are regarded as one of the main forms or types of teaching used, they are highly rated and advised by the curriculum as it is stated in the Social Studies syllabus for grade 4-7 that some topics if not all should be treated through sight-seeing. In this study, we have discussed the overview of the research problem, this is where the paper has created a mental picture of the current situation, by discussing the background of the study.

\subsection{Background of the Study}

The circumstance at Brendan Simbwaye Primary School was that learners' lack excursions in the Social Studies subject. With direct research in light of learners' last April (2017) examination, it was significant that a number of the learners at the school scored beneath $50 \%$, and those who passed did pass with low marks (50-60\%). It created the impression that the most consideration in field trips at the school was exceedingly given to Natural Science subjects while Social Studies subject was not given that privilege. Learners at the school were not given an opportunity to see what they learn in class and compare it to reality for them to comprehend or to interface the hypothesis of what they learn in class to unpretentious circumstances. This lack of field trip has developed into problem affecting the learners in their studies, coined as problem statement.

\subsection{Problem Statement}

When the researcher was sent for school based studies, it was observed that learners were failing to grasp information and knowledge taught theoretically in class when tested in class activities. Therefore, the researcher tried to find out why it was like that and the relationship between field trips and learners' performance in Social Studies were compared and this lead to the research question for the study.

\section{Main Research Question}

Why do learners at Brendan Simbwaye Primary school fail to comprehend what they learn theoretically in the Social Studies subject?

\subsection{Sub-Research Questions}

* Why do learners fail to grasp information they are given theoretically?

* What is the value of field trips in Social Studies learning?

What challenges do teachers' experience in conducting Social Studies' practical work?

The responses to the research questions will have significant value to the study as well as to other stakeholders in the field of teaching. 


\section{Significance of the Study}

The beneficiaries of this study are the teachers and learners at Brendan Simbwaye primary school the research site and the schools within the community. The study will help the teachers at the school and other schools and stakeholders in the Zambezi region and the country at large who are under the same predicament to understand the importance of carrying out field trips in Social Studies and its significance to other subjects that learners learn better by touching, seeing and feeling.

This study was guided by theoretical frame work for effective and efficient research work.

\section{Literature Review and Theoretical Framework}

The literature and theoretical framework are explained as below.

\subsection{Literature Review}

During the study, we used the works of authors below concerning the current literature in line with our study in order to help us have an informed position. Among other authors, Noel, (2007) said "Field Trips have for quite some time been utilized as a setting for instructing and learning in the social reviews and particularly in history training" (p. 21-23). In Social Studies, field work is essentially done in the field, these are spots that are out of class and may even be out of school. Here, the educator takes his/her learners to such places not for the sake of entertainment and relaxation but for instructive reasons. Mergens (2017) also defines field trips as guided tours, hands-on learning, interactive tasks and community service. Additionally, Stoddard (2009) accentuated that amid field trips learners get instructed through perception (viewing with the eyes and giving careful consideration of something) of the genuine question which they came to see and from there on learners think about and interface what they have seen with what they have hypothetically learnt back in class. This very important aspect of learning is overlooked at the aforementioned school.

As indicated by Stoddard (2009), field outings can give learners the chance to develop learning effectively through connecting with noteworthy spots, specialists, and ancient rarities. Noel (2007) said that "When incorporated into the educational modules and not utilized as prizes, field outings can be among the most profitable and effective modes of history teaching, especially local historic sites (p. 26-27).”

Field outings are a long way from now. Educators have been fusing them into their techniques for a considerable length of time since they empower understudies to encounter the physical world. Given their potential for influencing accomplishment, the theme of field treks has been the concentration of many research ponders Tesolowski, (1986), Rosenfield (1996), DeWitt and Storksdieck (2008), These reviews fundamentally include physical field trips that expand direction. 


\subsubsection{The Values of Field Trips in the Learning of Social Studies}

Concerning the value of field trips, Marzano (2011) says field trips empower instructors or teachers to grow children's learning beyond the walls of the classroom into the huge group outside. The estimations of field outings in Social Studies are; Good Performance of Learners, Providence of Historical Framework, Classroom Experience Reinforcement, Active Learning Participation Stimulant, Generation of Ideas for Assignments and Extension of Resources Available to learners in Classroom. Also, Atomatofa and Igwebuike (2013) emphasize the importance of field trips by saying that real life awareness helps learners link the theory learnt in class to the reality of what is learnt in the real world. These field trips encourage learners discover what the teacher might not see concerning what is taught in class. Atomatofa \& Igwebuike (2013) further say the following: "Field trips enable the learner exercise critical thinking and develop a logical system of reasoning which is essential for proper learning to take place (p 1)."

\subsubsection{Good Performance of Learners}

In the immediate subsection above, we have managed to highlight the importance of field trips to learners' performance. Stoddard (2009) agrees by saying that, "Field trips can result in greater achievement in all subjects" p. 59. By seeing genuine use of the lessons that they are learning in school, learners may probably comprehend and value the significance and pertinence of what they are learning. Alawad \& Mahgoub (2014) did a study concerning the relationship between field trips and the potential benefits of the trips to students' creativity and practices in art education and the findings revealed that field trips did help learners score higher than those who do not go for field trips and boosts their creativity and thinking skills. In comparison with the study under discussion it is clear that learners' poor performance in social Studies could have been as a result of lack of field trips

\subsubsection{Providence of Historical Framework}

English, (2010) argue that during field trips in Social Studies, learners show signs of improving comprehension of occasions in history, for instance, learners who visit the Smithsonian Museum may take in a couple of lessons about the Hispanic-American commitments to American prevalent music. Or, then again on the off chance that they visit a neighborhood craftsmanship, historical center, they may find out about the histories of certain workmanship developments.

\subsubsection{Classroom Experience Reinforcement}

(English, (2010) further believes that there is a requirement for Social Studies students or learners to apply what they learnt in real life, and this is another significance of field outings, if a teacher is discussing how children lived during Colonial America, he may take the class to an address by the author who wrote on the topic. This is an imperative point since it encourages learners to support their method for thinking by contrasting what they learn in class and what reality offers.

One of the greatest points of interest to handle outings is that they enable learners to have a 
real-world experience. This experience ought to unmistakably delineate and upgrade information educated by the curriculum. Visits to parks are generally tied in with the classroom educational program on the same or related subjects. By going to sites, learners get an immediate contact with the asset which can strengthen or supplement the classroom material. Besides, a visit brings alive and enhances information discussed in the classroom.

\subsubsection{Active Learning Participation Stimulant}

Behrendt and Franklin (2004) believes that although many students have negative feelings with respect to specific subjects, the existing educational experience and feeling of adventure that field trips involve can animate their brains and touch of their excitement toward generally detested subjects. For instance, in the wake of going to a planetarium or science, historical center, students who previously were bored in science class may be more intrigued. Likewise, a field outing to a play, workmanship exhibition hall or melodic execution may inspire students, fortify their psyches and influence them to study craftsmanship. Different learners may visit a historical center and create energized dispositions toward finding out about the past.

This study believes that in a recreation center the instruction program is an active learning experience. Regardless of whether the strategies are pretentious, critical thinking, diversions, physical movement, or other learning forums, the participants are not passive observers. Applying the familiar aphorism of "I hear and I forget, I see and I remember, I do and I understand," park instruction programs offer a learning knowledge that learners will convey with them; this experience can shape a reason for future choices as dependable grownups, and help to build up a protection ethic.

\subsubsection{Generations of Ideas for Assignments}

English, (2010) urges that in cases where a teacher assigns research papers to the class, a field trip could offer students inspiration. If a class has been assigned to write a paper about the political and economic factors that led to World War II, the teacher may bring them to the public library and help them find good books about World War II. This review sides with English and embraces that during this time when learners are taken to spots like libraries they won't just accumulate information required for the task but additionally pick up information on what a library is, how it is utilized and what it offers.

\subsubsection{Extension of Resources Available to Students in Classroom}

Council, (2009) Reports that, field trips extend learning by giving the students access to the genuine article. They represent and allow involvement with what has been perused about, seen on TV or PC programming. Teachers incorporate field trips in their units of study for this reason. This Study sides with the Council's report because Field excursions connect to the classroom since they are contextualized inside the classroom educational programs. Teachers browse historical center projects and shows to extend and strengthen coveted ideas.

The vast majority of researchers have concentrated on the benefits of field outings to the learners' executions in Social Studies yet however, there are a few zones that are forgotten 
which needs examine intercessions which is the place this paper will concentrate on, for example, the disservices of not presenting learners to this present reality through field trips, how field trips in Social Studies readies the better future for the learners and how field trips help the better teaching and learning hones in the specified subject.

\subsection{Theoretical Framework}

The theoretical framework for this research is based on the experiential learning theory. Daniel, (1984) claims that experiential learning theory provides a holistic model of the learning process which is consistent with how people learn, grow, and develop. The theory is called experiential learning to emphasize the central role that experience plays in the learning process. Simply put, experiential learning is learning from experience. The experience can be staged e.g. in the laboratory or left open e.g. everyday life experiences. Kolb (1986) and Bergsteiner, (2010) state that experiential learning theory sees the learning process as a cognitive process involving constant adaptation to, and engagement with, one's environment. Individuals create knowledge from experience rather than just from received instruction. Conflicts, disagreements and differences drive the learning process as learners move between modes of practical action, reflection, feeling and thinking. The learning driven processes can be glaringly observed if the right methodology and methods are implemented.

\section{Methodology}

Methodology is defined as the systematic, theoretical analysis of the methods applied to during the course of doing research for effective and efficient work delivery. It embraces the theoretical analysis of the methods and research design.

\subsection{Research Design}

This exploratory paper has taken the qualitative form as it depended on individuals' perspectives and their thoughts, though some quantitative methods were engaged. Quantitative Research tries to investigate and comprehend a central phenomenon in it, as it additionally intended to compare the variables which are "Field Trips" and "Learner's Performance". The study targeted grade 4-7 primary school social study classes as the population sample.

\subsection{Population Sample and Procedures}

Gay, Mills \& Airansian (2006) States that a sample is a group of people, things or occasions that speaks to the attributes of the bigger group from which the specimen is drawn, preferably a researcher would need to concentrate on the whole population. The population for this exploration depended on the randomly selected grades 4 - 7 Social Studies teachers and learners of the selected school in the Zambezi Region. Gay et al (2006) further explains that population is the bigger group with one or more characteristics common among the unit members of the sample where specimen is drawn.

By sampling, the study took over the system for random selection of a sample of many 
populations that the study concentrated on. From grades 4, 5, 6 and 7, the study included the selected teachers in Social Studies in each grade. Concerning the learners the targeted number was randomly picked, 1 learner from each class of grades 4, 5, 6 and 7 (A, B, C and D) which made an aggregate of 16 learners. From the sample, data were generated using the research instruments as discussed below.

\subsection{Research Instrument}

The instruments used to generate data was the questionnaire, to obtain information and opinion from the research respondents with reference to the questionnaire.

\subsubsection{Questionnaires}

Gay et al (2006) further says that a questionnaire is a research instrument comprising of a progression of questions and different prompts with the end goal of gathering information from respondents. The questionnaire is generally used particularly in descriptive survey studies. The questionnaires used comprised of composed questions and underneath each question there was an arrangement of a space where a person could answer the question.

Questionnaires were essential in the generating data since; they are practical, a lot of data was generated in a short-term and in a relatively cost-effective way. Questionnaires can be completed by the research participants or by any number of individuals with restricted impact to its validity and reliability. Data generated need to be analysed in order to make sense during the presentation of findings.

\section{Data Analysis and Presentation}

Since qualitative research is based on working with people's views and ideas, although the research had some numerical data or statistics, data was generated through the qualitative and qunatitave methods and thereafter it was interpreted by checking and coding of information used or constructed from the statistics collected. This implementation was done with the research ethics in consideration, for the benefit of research participants, real names were not used.

\subsection{Data Presentation}

At data presentation and analysis stage, this is the platform where the generated data were analyzed.

Teachers and learners were provided with questionnaires which included statements which they were told to rate from A to E where (Likert scale). A-Strongly agree, B- Agree, C-Disagree, D-Strongly disagree, E-No idea. From the data generated, the analysis below reflects the teacher's responses when they were interviewed.

\subsubsection{Teacher's Responses}

The following were the responses to the questions asked: 
How do the field trips help learners understand the Social Studies content better?

From the data given it showed that all of the teachers given the questionnaire, responded that they strongly agreed with the statement. This illustrated that field trip really helped learners understand the Social Studies content better and we concluded that field trips had a great impact on the learner's level of knowledge in Social Studies.

\section{During field trips learners shift their attention from learning to playing.}

According to the given findings of the research questionnaire, it showed that 2 teachers disagreed with the statement whereas the other 2 teachers strongly disagreed. This information shows that all the teachers disagreed with the statement and therefore we concluded that learning takes place during field trips and learners do not shift their attention from learning to playing.

\section{Is there any relationship between what learners see during field trips and what they learn} in class?

According to the given information it showed that 3 teachers strongly agreed with the statement and only one teacher indicated that he or she agreed with the statement given. This information showed that more teachers strongly agreed with the statement and from the given information we can deduce that the statement is correct and that there is really a great relationship between what learners see during field trips and what they learn in class.

\section{Field trips are a huge expense for schools.}

Given the collected data 1 teacher strongly agreed with the statement and another teacher agreed with the statement and the other 2 teachers disagreed with the statement. According to this information the researcher concluded that some teachers believe that field trips are a huge expense for schools and others did not believe that the issue of expenses given can be a setback in conducting field trips.

\section{Is field trips are better teaching strategies in Social Studies?}

The data given showed that 3 teachers strongly agreed with the statement that field trips were better teaching strategies in Social Studies, whereas only 1 teacher indicated that he or she agreed with the statement. This information confirms that field trips are really better teaching strategies in Social Studies Subject and that they help learners achieve better basic competencies and subject knowledge through field trips that will stay with them forever.

\section{Are the teachers enjoy taking learners on Field Trips?}

The information given showed that 1 teacher strongly agreed with the statement, 2 teachers agreed with the statement and one teacher strongly disagreed with the statement. The responses given showed that most of the teachers enjoyed taking learners on field trips whereas only a few believed that teachers do not enjoy taking learners on field trips.

\section{What are the teachers experience and challenges when conducting field trips?}

The data collected showed that all of the teachers agreed with the statement. This 
automatically confirmed that there is really indeed a lot of challenges that teachers experience when conducting field trips and this challenge can be seen as setbacks that limit most of the field trips to be undertaken at the school.

\section{Does the field trips arouse learner's interest in Social Studies Subject?}

This given data showed that 3 teachers strongly agreed with the statement, whereas only 1 teacher only agreed with the statement. According to the given information the researcher has no doubt that field trips arouse learner's interest in Social Studies Subject and this is a very great indication showing that field trips make leaners fall in love with the subject and this is one way in which it can boost their performance because they create a love and passion for the subject.

\section{Open ended questions}

\section{Do field trips bring learners into contact with the real world? Support your answer.}

The first respondent indicated a yes that field trips brought learners into contact with the real world because learners begin to elate theory content with what they see physically. The second respondent also said yes, because what they learn in class is what they are able to see outside the classroom, the third respondent indicated that a yes saying learners are exposed to more places than what they know as well as provide experience outside their everyday activities. The fourth respondent also indicated a yes, because learners do not only see what they learn in class, but they can even sometimes touch them and feel them. It showed that all of the respondents were in agreement and this was an indication which showed students that when they are taken for field trips they are really exposed to many things that they cannot understand when kept in class and this helps them make judgmental reasoning to real life situations.

\section{How does field trips contribute to the better performance of learners in social studies?}

The data collected showed that the first respondent said that learners learn by experiencing the real world outside the classroom, the second respondent indicated that field trips motivate learners through increased interest and curiosity and they also add variety positive attitude to learners. The third respondent said that when learners see things as they happen, it's hard for them to forget what they have seen. The fourth respondent said that learners pass with high symbols since they learn things that they see. According to the generated data there was a clear indication that field trips influenced the good performance of learners in Social Studies because of exposing them to the real world. It becomes more difficult for them to lose out or forget what they have seen outside than what they have learnt theoretically in class. After exhausting the teacher's responses as read above the research also followed up the data generated by learner's responses.

\subsubsection{Learner's Responses}

Learners were asked questions and this is how they responded.

Does the field trips help learners understand the Social Studies content well and get better 


\section{grades?}

The responses indicated that 13 learners strongly agreed with the statement and only 1 agree with the statement. From the data it showed that all the learners agreed that field trips help learners understand the Social Studies content better and leads to their achievement of better grades in the mentioned subject Shakil, Faizi and Hafeez, (2011).

\section{Do learners equally taken in both Natural and Social Science field trips?}

Out of 14 learners it showed that 3 of them agreed to the statement above, 5 learners disagreed to the statement, 4 learners strongly disagreed and only 2 indicated that they had no idea. According to the responses, it showed that most of the learners disagreed with the statement and only a few agreed with the statement. We therefore concluded that Natural and Social Science are not equally practicing field trips at the selected school.

\section{Are learners more interested to be taught through field trips than being taught in classrooms?}

According to responses collected, 4 learners strongly agreed with the above statement, 6 learners agreed with the statement and 2 learners disagreed with the statement, 1 learner had also strongly disagreed with the statement and only 1 learner indicated that he or she had no idea. This information revealed that most learners very interested in field trips that to be taught in classrooms. When learners are taught in an environment of their interest they are highly to achieve better grades, however a few had disagreed with the statement meaning classroom environment could be favorable for them.

\section{Are learners most of the times taken for field trips?}

The given data showed that 7 learners disagreed to the statement, 6 learners strongly disagreed and only 1 learner indicated to have no idea of the above statement. We therefore concluded that all of the learners disagreed with the statement, meaning there was no doubt field trips were not taken at all indicating that they was not much practical work done in Social Studies.

Does the field trips provide learners with 1st hand information that they won't easily forget?

Out of 14 learners, 10 learners strongly agreed with the statement, 3 learners agreed and only 1 learner disagreed with the statement. According to the information given it showed that all of the learners who understood the statement had indicated that Field Trips provide learners with firsthand information that they will not easily forget and we therefore concluded that field trips were a very important teaching strategy when we want learners to keep what they learn in mind for long Neumann (2010).

\section{How does the field trips encourage active learning and participation in class?}

Given the raw data it showed that 5 of the respondents indicated that they strongly agreed with the statement, 7 learners only agreed and only 1 learner strongly disagreed with the statement and another learner indicated having no idea of the statement. Since most of the 
learners had shown that they were in agreement with the statement this implied that learners believed that Field trips encourage active learning and participation in class.

\section{Does the field trips offer students or learners inspiration in life?}

The responses indicated that 9 learners strongly agreed with the statement, 2 learners only agreed, 1 leaner disagreed and 2 learners indicated to have no idea. This information confirmed that learners understand that when they are taken for outings they see and meet a lot of people that they can look up to in life and give them hope to be successful in life that someday they can follow the same careers that they have.

Field trips do not only teach learners about subject content, but shows them reality about the real world.

The gathered information revealed that 9 learners strongly agreed with the statement, whereas 4 learners only agreed and 1 learner disagreed with the statement. This information implied that most of the learners believed that field trips did not just teach them about what they are expected to know as part of the subject content, but it opens up their mind and shows them the reality that brings them close to what the world has for them apart from classroom lessons.

\section{Open ended questions}

\section{What do you think are the importance of field trips to your learning?}

Most of the learners had difficulty in responding to the question, but however a few gave reasonable answers based on the question above. A few who have responded well to the question indicated that field trips brought them close to many things that they earlier failed to understand and sometimes believe to be existing, they said it was the platform which they have to question the world regarding the Social Science world and its people. They said field trips keep them focused on what they learn in class and in the end they improve their performance in the subject.

\section{During field trips learners shift their attention from learning to playing, do you agree or disagree with the statement, support your answer.}

According to the given data it showed that a few learners agreed to the statement because in field trips when some learners see things they will start calling each other names of the things they have seen and make jokes forgetting the part of learning. However a few disagreed with the statement because it was the only opportunity that they have and sometime it comes once in a life time so they wouldn't risk to play with it instead they focus on the field trip. They believe fields trips are for them to learn not for making jokes as they might lose focus. This showed that the majority of the learners and teachers were really in need of field trips not as an opportunity to play and have fun therefore, this led to the use of appropriate research ethics during the study. 


\section{Research Ethics}

The researcher kept up exclusive expectations of expert led and scholarly trustworthiness in the conduct of the research. Members were treated with dignity, and their rights were secured by insuring that they were told about the conceivable advantages of being in the study and of whether there were any expenses related with being in the study. People were asked to willfully partake in the review and sign a consent letter. No one was compelled to participate. The members stayed anonymous all through the study. Individual subtle elements, for example, pseudo names were used during the research processes. Taking everything into account, this investigation inquired about the influence of field trips on the learner's performance in Social Studies in view of the examination discoveries, the accompanying conclusions were drawn

\section{Conclusion}

The discoveries demonstrated that fewer teachers made utilization of field trips in teaching Social Studies among which one of the reasons was that the schools did not embrace field trips by any stretch of the imagination. Financial constraints kept teachers away from having an interest in field trips. The discoveries of this investigation likewise showed that to a high extent field trips helped learners to complete viable works in Social Studies. It uncovered that to a high degree field trips encouraged learners to build up the capacity of commitment and this fundamentally upgrades their academic performance in Social Studies (Tesolowski 1986). Teaching using ordinary techniques is insufficient to propel learners to explore freely or to have first-hand information on a specific phenomenon. This paper concluded by expressing that the classroom is a restricted situation and the learning of Social Studies must go past the four dividers of the classroom (Rosenfield 1996). The utilization of field trip ensures that teachers and learners meet their obligations by guaranteeing its use to encourage the learning of useful concepts. Field trips will likewise enable students to secure, hold and help to make abstract thoughts more concrete. For effective field trip here are recommendations that emanates from the research.

\section{Recommendations}

Subsequent to having led an examination on the topic: the influences of lack of field trips on the learners' performance in Social Studies at the selected school and in light of the result of the examination, this study along these lines suggest the accompanying recommendations;

- Making field trips is a need to all and should be in the syllabus.

* Government should give finances particularly for field trips.

* Teachers should sort out class touring (teaching small field trips).

* Workshops on the significance of out of class teaching should be conducted. 


\section{References}

Atomatofa, R., \& Igwebuike, T. B., (2013). A Test of the Efficacy of Field-Trip and Discussion Approaches to Teaching Integrated Science within a Constructive Flavour Journal of Education and Practice, 4, 13.

Behrendt, M., \& Franklin, T. (2004). A review of research on school field trips and their value in education. International Journal of Environmental and Science Education, 9(3), 235-245. https://doi.org/10. 12973/ijese.2014.213a

Bergsteiner, G. (2010). Kolb's Experiential Learning Model: Critique From a Modelling Perspective. Studies in Continuing Education, 20(1), 29-46. https://doi.org/10.1080/01580370903534355

Council, T. N. (2009). Field Trips as an Advantage to Classroom Instruction. University of Maine: University of Maine Press: Maine.

Daniel, K. (1984). Experiential learning: Experience as the source of learning and Development. New Jearsy: Prentice-Hall.

DeWitt, J., \& Storksdieck, M. (2008). A Short Review of School Field Trips Key Findings from the Past and Implications for the Future. Visitor Studies, 11(2), 181-197.

English, T. (2010). Field Trips in Social Studies. New Jersey: Pearson Education.

Gay, L., Mills. G., \& Airansian, P. (2006). Educational Research: Competencies for analysis and applications $\left(8^{\text {th }}\right.$ ed.) New York: Prentice Hall.

Jay, P. (2014). Barriers that Teachers Experience in Conducting Field Trips. Cape Town: Cape Town Press.

Alawad, A. A., \& Mahgoub, M. Y., (2014). The Impact of Field Trips on Students' Creative Thinking and Practices in Arts Education. Journal of American Science, 10(1), 46-50.

Marzano, R. J. (2004). Building Background Knowledge for Academic Achievement. Association of Supervision and Curriculum Development, Alexandria, VA

Mergens, David. (2017). The Impact of Educational Travel on High School Social Studies Students. University of British Columbia Library. Retrieved 15/05/2018 from http://creativecommons.org/licences/by-nc-nd/4.0/

Neumann, R. (2010). Kolb's Experimental Learning Model. Critique from a modelling perspective. Studies in Continuing Education, 32(1), 29-46. https://doi.org/10.1080/01580370903534355

Noel, M. (2007). Elements of winning field trip. Kappa Deltra Pi record, 44(1), 42-44. https://doi.org/10.1080/00228958.2007.10516491

Rosenfield, H. J. (1996). The Importance of Excursions In Teaching and Learning. University of Bahama. Bahamas. Bahamas Press: 


\section{Macrothink}

International Journal of Education ISSN 1948-5476 2018, Vol. 10, No. 2

Shakil, A. F., Faizi, W., \& Hafeez, S. (2011). The need and importance of field trips at highlevel in Karachi, Pakistan. International Journal of Academic Research in Business and Social Sciences, 2(1), 1-21.

Stoddard, J. (2009). Toward a virtual field trip model for the social studies. Contemporary Issues in Technology and Teacher Education, 9(4), 412-438.

Tesolowski, L. J. (1986). The Influence of Field Trips In The Academic Perfomance of Learners. London: Oxford Inc Press.

\section{Copyright Disclaimer}

Copyright for this article is retained by the author(s), with first publication rights granted to the journal.

This is an open-access article distributed under the terms and conditions of the Creative Commons Attribution license (http://creativecommons.org/licenses/by/3.0/). 